\title{
First record of the common bream (Abramis brama) introduced to the Iberian Peninsula
}

\author{
Lluís Benejam, Joaquim Carol, Carles Alcaraz \& Emili García-Berthou ${ }^{1}$ \\ Institut d'Ecologia Aquàtica, Universitat de Girona, E-17071 Girona, Catalonia, Spain. \\ ${ }^{1}$ Corresponding author: emili.garcia@udg.es
}

\begin{abstract}
This is the first record of the common bream, Abramis brama (Linnaeus, 1758), introduced into the Iberian Peninsula. Eight individuals of this cyprinid fish species were captured (of a total of 978 fish) in the Boadella Reservoir (Catalonia, Spain) on August 18, 2004. This reservoir is only $14 \mathrm{~km}$ away from France, where the bream is native, and contains several exotic freshwater fish that are still not widespread in Spain. The further introduction of species and the illegal translocation of the bream by anglers to other Iberian river basins should be controlled by the Spanish administration.
\end{abstract}

Keywords: common bream, Abramis brama, Cyprinidae, Boadella reservoir, Muga River.

\section{RESUMEN}

Se da la primera cita de la brema, Abramis brama (Linnaeus, 1758), introducida en la Península Ibérica. Se capturaron ocho individuos de esta especie de ciprínido (de un total de 978 peces) en el embalse de Boadella (Cataluña, España) el 18 de agosto de 2004. Este embalse está a sólo $14 \mathrm{~km}$ de Francia, donde la brema es nativa, y contiene otras especies exóticas de peces, que aún no son frecuentes en la península. La introducción ilegal de otras especies y la translocación de la brema a otras cuencas ibéricas por parte de pescadores deportivos debería ser controlada por la administración española.

Palabras clave: brema, Abramis brama, Cyprinidae, embalse de Boadella, río Muga.

The Common Bream, Abramis brama (Linnaeus, 1758), is a cyprinid fish native to most of Europe and western Asia. However, like many other European freshwater fish (García-Berthou \& Moreno-Amich, 2000), the common bream is not native to the Iberian Peninsula, where it was not known to be present until now (Doadrio, 2002).

During a fish survey with boat electrofishing and multimesh gillnets (stretched mesh ranging 29-253 $\mathrm{mm}$ ), eight individuals of this species were captured in the Boadella Reservoir, NE Spain (42 20' $15^{\circ}$ " N, 2 $21^{\circ}$ '07" $\mathrm{E})$. The individuals had all the distinguishing features of the species, including fin ray formulae (examined in detail for two fish: dorsal III/10, anal III/24-25, pectoral I/14-16, pelvic II/8, caudal 19) that agree with those reported for the species. The lateral lines had 50-54 sca- les and the two fish were aged $2+$. We captured 978 individuals on August 18, 2004, 856 by littoral electrofishing and 122 by gillnetting at 5$10 \mathrm{~m}$, of depth. Of the 122 gillnet captures, eight were bream $(6.6 \%)$, ranging $180-301 \mathrm{~mm}$ and 156-257 of total and fork length, respectively. These bream were captured with three different nets, separated a total of $c a .3500 \mathrm{~m}$ within the reservoir. Given the large size of the reservoir (maximum surface area of 364 ha, maximum capacity of $61.1 \mathrm{hm}^{3}$ ) and the observed abundance and distribution of bream, a large number of individuals must have been introduced or it could also be an old introduction. We did not detect this species in a previous survey carried out on 7-28 February 2003, but fewer individuals were captured during that survey (140, of which only 18 were 
captured by gillnetting) so the species might have already been introduced by that date. The common bream is native to France, which lies only $14 \mathrm{~km}$ from the reservoir, and is abundant in standing waters throughout Europe, typifying the last of the four longitudinal zones of most European rivers (Bruslé \& Quignard, 2001). Therefore it is likely to establish itself in the Boadella Reservoir and will easily spread downstream of the river basin (Muga River), where it might harm native biota.

Because of its proximity to the French border and to the most important geographical entryway to the Iberian Peninsula, the Boadella Reservoir has unfortunately many exotic species, at least nine fish species (six of them native to France), and has been one of the first localities of introduction for other species still not widespread in Spain, such as the perch (Perca fluviatilis), the roach (Rutilus rutilus), the pikeperch (Sander lucioperca), or the rudd (Scardinius erythrophthalmus). This reservoir along with the Banyoles Lake have been shown to be some of the main entrance points of exotic freshwater fish in the Iberian Peninsula (GarcíaBerthou \& Moreno-Amich, 2000; Zamora \& Pou-Rovira, 2003) and should be more controlled by fish management authorities.

Prevention measures should be taken by the administration to avoid the spreading of this new exotic species to other reservoirs and river basins. This has not been the case with numerous previous introductions in the Iberian Peninsula, and several species such as the bleak (Alburnus alburnus) and the wels (Silurus glanis) are being illegally spread by anglers nowadays (Carol et al., 2003). Eradication of introduced fish is practically impossible in large freshwater eco- systems, so prevention of further introductions and translocations is of primary concern.

\section{ACKNOWLEDGEMENTS}

We thank Quim Pou-Rovira for estimating the age of the bream. This study was financed by the Spanish Ministry of Science and Technology (REN2003-00477) and the Catalan Ministry of Universities, Research and Information Society (DURSI, Catalan Government Distinction Award for University Research 2004 to EGB). JC and CA held doctoral fellowships from the University of Girona and the Spanish Ministry of Education (FPU AP 2002-0206), respectively.

\section{REFERENCES}

BRUSLÉ, J. \& QUIGNARD, J.-P. 2001. Biologie des poissons d'eau douce européens. Editions Tec \& Doc, Paris. 625 pp.

CAROL, J., BENEJAM, L., POU-ROVIRA, Q., ZAMORA, L. \& GARCÍA-BERTHOU, E. 2003. First record of white bream (Abramis bjoerkna) in Catalonia (Spain) and new introductions of exotic fish (Alburnus alburnus, Sander lucioperca and Silurus glanis) into Catalan river basins. Butll. Inst. Cat. Hist. Nat., 71: 135-136.

DOADRIO, I. (ed.) 2002. Atlas y libro rojo de los peces continentales de España. Ministerio de Medio Ambiente, Madrid. 374 pp.

GARCÍA-BERTHOU, E. \& MORENO-AMICH, R. 2000. Introduction of exotic fish into a Mediterranean lake over a 90-year period. Arch. Hydrobiol., 149: 271-284.

ZAMORA, L. \& POU-ROVIRA, Q. 2003. New introductions and present population of fishes in Lake Banyoles. Butll. Inst. Cat. Hist. Nat., 71: 136-139. 